\title{
Fact-Checking, a Public Service Value in the Face of the Hoaxes of the Healthcare Crisis ${ }^{1}$
}

\author{
María José Ufarte-Ruiz \\ Belén Galletero-Campos \\ Ana María López-Cepeda \\ University of Castilla-La Mancha (Spain)
}

The dissemination of fake news is an increasing issue in the media ecosystem, which has worsened with the current healthcare crisis. Pandemic-related hoaxes challenge media, which have not hesitated to implement different plans to combat these contents. The objective of this research is to analyse the structure, make-up and procedures of fact-checking units that have been created in the newsrooms of the public service media (PSM) in Spain to refute false and unreliable information related to coronavirus. Two initiatives were studied: RTVE Verifica, belonging to the Spanish Radio and Television Corporation, and Coronabulos, from the public entity of the Basque govern- ment, EiTB. The method used is based on case studies, web content analysis and in-depth semi-structured interviews with those responsible for these departments. Such a triangulation of techniques has allowed us to draw conclusions and provide interesting examples to the research. The results reveal that these sections use traditional techniques and technological applications to verify content related mainly to healthcare and pseudoscientific information, which are published on corporate websites and social media.

Keywords: hoaxes, coronavirus, healthcare crisis, fact-checking, public service media.

1 This article is part of the work carried out within the framework of the research project (RTI2018-096065-B-I00) of the State Program R + D + I aimed at the Challenges of Society of the Ministry of Science, Innovation, and Universities (MCIU by its acronym in Spanish), State Research Agency (AEI by its acronym in Spanish), and the European Regional Development Fund (ERDF) on "New values, governance, financing, and public audiovisual services for the Internet society: European and Spanish contrasts". 

The coronavirus pandemic (COVID-19) caused a strong impact in public health. Information pieces disseminated up until now indicate that it could have been originated in China on December 2019 (Pérez, Meso, and Mendiguren, 2020), but swiftly extended around the world, causing a significant health and economic crisis. The disinformation and fake news related to this crisis and its fast dissemination created "infodemics" (Abellán, 2020), no longer residual and reaching considerable levels. In Spain, one of the most affected countries by the pandemic, more than $80 \%$ of population has received coronavirus related hoaxes during lockdown, especially through social media and WhatsApp, according to the study conducted by the Digilab research group Ramon Llull University (Castillo, 2020).

Delgado López-Cozar and Martín-Martín (2020) think that a possible cause resides in the increasing use of non-reviewed biomedicine documents about COVID-19 in repositories, that influence conversations on social networks, thus generating disinformation. The magnitude of these practices have led the European Commission to alert about the destabilisation risks this phenomenon might cause (Comisión Europea, 2020) and to create different initiatives to counter it. For instance, there is the case of the website fighting disinformation, which helps to dissection coronavirus related hoaxes and provides the keys to dismantle unreliable information. Another of the combat focus is located in Brussels, in a unit created in 2015 to fight against disinformation. It is EUvsDisinfo, which depends on the European External Action Service and which currently publishes extensive studies that dismantle fake news about COVID-19.

Blanco-Herrero and Arcila-Calderón (2019) emphasise that these contents are introduced as one of the challenges of the contemporary journalism, which shall provide a social function in large social impact events, such as catastrophes or humanitarian crises (Toledano and Ardévol-Abreu, 2013). In line with these proposals, and in the pandemic context, public media must join forces and lead the fight against fake news. It is necessary to protect their independency and sustainability (EBU, 3 April 2020b), to implement tools and connection processes with the audiences, in order to keep them informed (EBU, 31 March 2020a).

In this sense, several public audiovisual media have activated different policies and projects to dismantle fake news. In Germany, for example, the channel networks ARD or ZDF publish decalogues or guidelines on their websites so that users learn to identify them, like the Federation of Regional Organizations of Radio and Television (FORTA) in Spain. On the other hand, the Belgian VRT and the Danish DR have programmes targeted to youth in collaboration with educational centres. And the German SWR and the Finnish YLE have provided videogames to users, like Fake Finder and Troll Factory respectively, to show how hoaxes are spread. There are also media with permanent fact-checking teams, like Reality Check in BBC (López, Ufarte, and Murcia, 2019), or RAI in Italy, which has reinforced this service in the past weeks to create a surveillance and confirmation team about coronavirus related information, based on the advice of a committee composed of virologists, physicians and scientists that assess the huge volume of news received by the newsroom.

In Spain, RTVE promoted, since the beginning of March, a specific team to deny these hoaxes. In addition, the public radio and television broadcasting net- 
works of FORTA undertook a series of actions to help citizens differentiate true contents from those that are not. In the Basque Country, EiTB created a work group in its newsroom and Castile-La Mancha Media created a repository in its website about "Coronavirus Hoaxes", where advise against fake news are provided. Corporación Aragonesa, on the other hand, provides a service dedicated to the identification of "coronafrauds", while other corporations have incorporated the analysis of coronavirus related hoaxes into different programmes, just like Canal Sur, Radio Televisión Canaria, Radio Televisión de Galicia, the Balearic IB3 or Corporación Catalana de Medios Audiovisuales (Colpisa, 2020). The latter has a fact-checking team in Catalunya Radio since 2019, that dismantles hoaxes in the programme Catalunya Migdia.

The objective of this paper is to analyse the performance of fact-checking initiatives created by Spanish public audiovisual media to deny fake news about coronavirus. It is not possible to find significant previous contributions about this study subject and, considering the descriptive character of the research, there is no initial hypothesis, but rather several research questions: Q1: How do these teams work?; Q2: Are they composed of journalists or rather of different professional profiles?; Q3: How is the fact-checking carried out?; Q4: What are the contents fact-checked the most?; Q5: How many hoaxes have been factchecked since the state of alarm was declared?; Q6: What are the channels used by media to present fact-checked information to the public?

We have opted for the analysis of public media because they should promote the fake news denial as an added value of the public service they represent. In addition, previous studies show that the European public prefers this kind of media to get informed about the COVID-19 pandemic (EBU, 25 March 2020), which convey a higher reliability compared to private media. Along with the radio and television nationwide broadcasting networks in Spain, we have analysed the regional public networks, due to their proximity with the closest communities. Local networks have not been investigated because hoaxes circulate beyond the local scope and most political decisions about the pandemic in Spain, are being made in the national and regional scope.

\section{THEORETICAL FRAMEWORK}

The fake news are not a characteristic and exclusive feature of current times (Burkhardt, 2017; Petroni, Massa, and Anzera, 2017), but instead they have been present in the history of communication (Salas, 2019), especially during the large military conflicts and in-between wars to favour specific interests (Barragán and Bellido; 2019; Bloch, 1999; Schudson and Zelizer, 2017). However, the new media ecosystem, characterised by becoming an informational disorder context (Wardle and Derakhshan, 2017) due to the eclosion of social networks (Haigh, Haigh, and Kozak, 2017; Pavlik, 2013), has contributed to the proliferation of this sort of contents (Jan and Kim, 2018). Fake news are produced with the outlook of journalistic information (Ufarte-Ruiz, Anzera, and Murcia-Verdú, 2020) but supported instead by mistaken, exaggerated or ma- 
nipulated data (Alandete, 2019; Khaldarova and Pantti, 2016), and high levels of factuality and deceit (Tandoc, Lim, and Ling, 2018), in order to create new interpretations (Balmas, 2012) and favour ideological or economic interests (Allcott and Gentzkow, 2017).

These "alternative facts" (Macías-Varela, 2017) currently linked to the political ground and disseminated on Internet or other media (Cambridge Dictionary, 2018) played a relevant role in the presidential elections of 2016 in the United States, when Donald Trump questioned the veracity of the information of some media during his electoral campaign (Jankowski, 2018; Greenberg, 2017). They were also present during electoral processes in France, United Kingdom, Germany, and Spain (Lowrey, 2017).

The fake news are a "troublesome oxymoron" (Blanco-Alfonso, García-Galera, and Tejedor-Calvo, 2019) of which some common features are progressively disclosed. Derakhshan and Wardle (2017) emphasise their pernicious intentions, while Vosoughi, Roy, and Aral (2018) highlight the virulence and spreading speed. Zaryan (2017) and López-Vidales, González-Aldea, and Medina-Viña (2011) refer to the social and intergenerational impact, while for Catalina-García, Sousa, and Cristina-Silva (2019) the problem lies in whether audiences are able to differentiate fake news from those that are not, because they often grant credibility to the information that best fits their view of the world (Mihailidis and Viotty, 2017). On the other hand, Amorós (2018) focuses on their structure, composed of three elements: an impactful headline, a revelation that is reaffirmed or that outrages the reader and a legitimate and reliable outlook. In any case, the effects are negative because the truth is confused with the lie; the credibility towards false increases (Rapp and Salovich, 2018) and the legitimacy of the democratic discourse is put at stake (Champy; 2011; Codeluppi, 2018; Fisher, 2018; Magallón-Rosa, 2019; McChesney, 2014).

The formula adopted by journalism to fight the proliferation of these texts and mitigate their effects, has been the verification of information or fact-checking (Geham, 2017). It is a journalistic practice based on the a posteriori confirmation of information published by media and on the fact-checking of statements or comments made by political leaders or relevant figures (Mantzarlis, 2018), in order to contribute in a more efficacious manner to the accountability of public representatives and to the best information of citizens, a key issue for reinforcing democracy (Nyhan and Reifler, 2014).

Although the origin of fact-checking dates back to 1913 (Ayuso and Bauzá, 2018) and its practice is indispensable in any journalistic production process (Ufarte, Peralta, and Murcia, 2018), the fact is that in recent years this activity has become popular and the journalistic initiatives destined to these tasks have multiplied (Spivak, 2011; Stencel, 2016). Many media and independent platforms have created sections, work groups or spaces targeted to fact-checking information published in other media, disseminated through social networks, or announced by the main political leaders (Cherubini and Graves, 2016). The census of the information fact-checking projects made by the Reporters' Lab of Duke University (Duke Reporter's Lab, 2019) counts a total of 328 fact-checking initiatives in 80 countries, out of which 237 are active and 91 inactive until 1 
April 2020. This expansion is justified by the far reaching feature of fake news (Vizoso and Vázquez-Herrero, 2019).

Furthermore, this practice has made room to a new professional profile: fact-checkers (Ufarte-Ruiz and Manfredi-Sánchez, 2019), who use verification techniques and technological tools (Arcila-Calderon, Barbosa-Caro, and Cabezuelo-Lorenzo, 2016; López-García, Toural-Bran, and Rodríguez-Vázquez, 2016; Uscinski and Butler, 2013), besides the analysis, interpretation and the reconstruction of information (Amazeen, 2015; Renó and Flores, 2014), to clarify and shed light about information pieces elaborated in an inadequate or false manner (Casero-Ripollés and Cullell-March, 2013; Paniagua-Rojano, Gómez-Aguilar, and González-Cortés, 2014). Therefore, their mission is to uncover discourses, reconstruct and follow the course of spreading of fake news (Graves, 2016).

\section{METHODOLOGY}

The objective of this research is to analyse the structure, work methodology and publication of denials made by the fact-checking initiatives that have been implemented in Spanish public audiovisual media to combat fake information about coronavirus. This is a relevant matter considering the urging need of advocating journalism models based on the excellence and quality in the face of the invasion of others that grant a greater value to traffic rather than the relevance of the content published.

The method used to reach this purpose is the case study, which according to García-Avilés and Carvajal (2008), allows to explain the transformations in the media industry, because resources like interviews, participant observation, questionnaires or bibliographic documents are available for the researcher in order to get enough contextualisation of the studied phenomena.

This technique, that allows the combination of multi-method strategies (Rivas-Roca, García-Gordillo, and Caro-González, 2020) has developed in four stages, where a methodological triangulation was carried out (Gaitán-Moya and Piñuel-Raigada, 1998). Like Gómez-Diago (2010) and Soler-Pujals and Enríquez-Jiménez (2012) state, it consists of contrasting information between different sources to obtain enough contextualisation of the studied phenomena.

In first place, the scientific literature was reviewed, which is part of the secondary research (Codina, 2017), and that has allowed to know the main contributions to the state of the art.

In a second stage, all the public audiovisual media were located, both of national as well as regional circulation, which have undertaken actions in the context of the coronavirus crisis to fact-check fake news disseminated about the pandemic. As a result of this first search, it was discovered that the different autonomic public audiovisual media included in FORTA and Corporación Extremeña de Medios Audiovisuales (CEXMA) have initiated different measures to fact-check contents circulating about the healthcare crisis.

Out of the 14 audiovisual media analysed, only two have generated a specific space to visibilise the fact-checking tasks about the pandemic since the state of 
alarm was declared by the Government. Specifically, the fact-checking teams analysed in this study belong to Corporación de Radio y Televisión Española, RTVE Verifica, and the team of the public entity of the Basque Government, EiTB, Coronabulos.

In a third stage, an analysis template was elaborated to be used for each one of the analysis units selected. This template has been completed, in an initial stage, based on the analysis of the web content (Herring, 2010), which complements the analysis of traditional content (Bardin, 1977; Krippendorf, 2004). Among the investigated variables, there is the description of the section, the work methodology and the study of the news that were denied since 17 March, when the fact-checking teams were created, until 17 April.

Table 1. Analysis parameters

\begin{tabular}{l|l}
\hline Fact-checking service description & $\begin{array}{l}\text { Name of the company; 2) Origin of the initiative; 3) Number of } \\
\text { employees; 4) Staff profile; 5) Main objectives; 6) Collaborations with } \\
\text { entities. }\end{array}$ \\
\hline Fact-checking methodology & $\begin{array}{l}\text { 1) How is the fact-checking conducted; 2) Techniques used; 3) Most } \\
\text { fact-checked contents; 4) Number of completed fact-checking. }\end{array}$ \\
\hline Fact-checking publication & $\begin{array}{l}\text { 1) Circulation routes of the fact-checked content; 2) How are fact- } \\
\text { checks formally presented. }\end{array}$ \\
\hline
\end{tabular}

Source: Own creation.

In a fourth stage, this exploratory study has been completed by conducting semi-structured in-depth interviews with the staff responsible of these initiatives. In the case of RTVE, we interviewed Miriam Hernanz, subdirector of new interactive narratives of RTVE, while in EiTB, we interviewed Lontzo Sainz, director of digital transformation. The topics that clustered questions included the contextual aspects of the initiative and the teamwork flow, among others. With the responses obtained, a detailed description of each one of the study cases was elaborated.

\section{RESULTS}

\section{VERIFICA RTVE}

The work team that developed the Verifica RTVE initiative is framed in the digital area of the entity. Initially, it worked intermittently during 2019, focusing on information fact-checking in the two elections that took place that year. However, the healthcare crisis produced by coronavirus and the declaration of the state of alarm have become the ultimate boost to keep the initiative stable during the recent weeks. It is a multidisciplinary team of eight professionals: Miriam Hernanz, subdirector of new interactive narratives of RTVE, plus three documentalists and four journalists of the digital sector and specialised in fact-checking. 
The objective of the team is fact-checking hoaxes and pernicious coronavirus related information made viral on social networks and instant messaging services during lockdown, in order to provide quality service directly to citizens. In order to do this, the team maintains collaboration networks with some international entities, like the fact-checking group of the European Broadcasting Union, with which different information has been denied, like the video that circulated on the week of 4 April about a morgue saturated with corpses that belonged to a Guayaquil Hospital in Ecuador and not to Spain, Italy, Chile or New York, like stated initially.

Regarding the fact-checking methodology, the first step is to monitor social networks to identify the most viral themes. This is a screening process made with tools like CrowdTangle or TweetDeck. On the other hand, the team makes a selection, prioritising the information related to consumption and pseudo-scientific remedies, questions that generate social alarm and themes that infringe cybersecurity or that harm a person's dignity, because false contents are spread in his or her behalf. Hernanz nuances:

Some fact-checking can be completed on the same day and others need several days of research and more specialised techniques, like the inverse search or the picture geolocation.

Regarding the volume of the fact-checked content, Verifica RTVE sums a total of 152 pieces since 17 March until 17 April. In addition, through the WhatsApp phone number $(+34676.676 .148)$ it has responded in a direct manner to more than 350 queries made by citizens about truly diverse themes, that include questions related to sick leaves up to doubts about body care. The archive of these responses, has allowed to elaborate a data base that feeds the voice service Alexa and provides a direct and instant feedback to the user through the voice device at home. Hernanz explains:

These are different uses for fact-checking, not limited to an article on the web or a report in the TV, but instead there is a direct feedback with users to address their concerns.

Regarding the publication or fact-checking, the team uses different channels. In the corporation's website the denials are posted in the form of news, namely, by using a headline and a body text, where the data contributing to the falsehood of information is explained. Furthermore, the text shows the word "HOAX" or "FALSE" in large font (Image 1). Likewise, Verifica RTVE provides a daily section in Radio 5 and Radio 4, in Catalan, and has a weekly section in the television programme $\mathrm{La}$ Mañana de la 1, with teams adapted to its type of public. The Facebook (Lab RTVE, 8,054 followers), Twitter (@lab_rtvees, 13,527 followers) and Instagram (lab_rtve, 4.751 followers) profiles are also used to deny coronavirus related hoaxes.

Likewise, there is usual collaboration with the news editorial office of RTVE. Hernanz states:

In the Intranet, a special site was created about coronavirus and Verifica RTVE is mentioned as element of documentation reference. At the same time, we archive all that material in case editors or writers need those videos or viral material. 
Image 1. Information fact-checked by Verifica RTVE

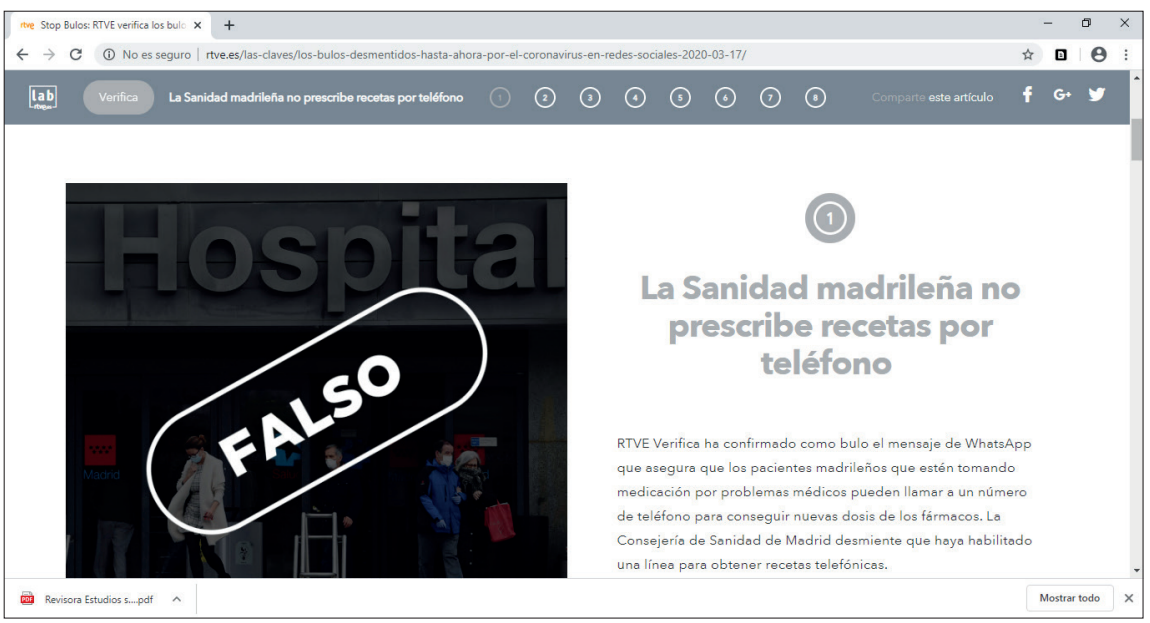

Source: $<$ http://www.rtve.es/>.

\section{EITB}

The Euskal Irrati Telebista group activated its fact-checking service under the name of "Coronabulos", on 16 March, in order to provide a public service of contrasted and true information about coronavirus. Although this section was generated in a specific manner to fight against the disinformation that emerged during the healthcare crisis; back in 2018, the group already started an education campaign (inFORMAZIOA) and elaborated a decalogue to identify fake news on Internet and social networks. This is a sample of the endeavour to disseminate mechanisms that enable citizens to discern quality information. The Coronabulos service is born thanks to Lontzo Sainz, the director of digital transformation, and it is composed of three professionals: Sainz as coordinator, a journalist and a web analyst, responsible of elaborating two daily reports after the screening of queries received through WhatsApp (+34 600.900.454) and email (coronabulos@ eitb.eus).

In addition, to articulate the service, they have two outsourcing collaborations: The Association of Digital Volunteers of Euskadi Emergencies VOST Euskadi and the journalistic project Maldito Bulo, with whom they keep daily contacts to assess the demands they receive and be up-to-date about what topics are being managed by each entity. A third cooperation route is the scientific community, through the dissemination programme La Mecánica del Caracol, hosted by the journalist Eva Caballero in Radio Euskadi. Its network of expert sources facilitates contrasting studies and information which veracity is not fully guaranteed, either because they are pseudo-scientific remedies, or because they disseminate preliminary non-conclusive outcomes. 
Regarding the fact-checking systems, the Basque radio television broadcasting network has not developed a specific work method, but instead manages hoaxes using the classic journalistic praxis, by means of contrast of sources, trying to get to the origin of information and by consulting scientific experts, for instance, University of the Basque Country. Furthermore, the broadcasting networks that belong to the group and that are deployed across the autonomous community are helpful, because they have contacts in different areas. For the selection of themes to be fact-checked, the priority is to analyse the queries that repeat the most and, therefore, have a greater impact, and also those of local scope, reinforcing its mission of service to the Basque community.

Since the beginning, this service has received 1,500 fact-checking requests, $19 \%$ through email and the rest through WhatsApp, making room to a total of 62 pieces that can be read on the section "Bulos del coronavirus" in the website of the group. Out of these, 56 are denials and 6 are information pieces that refer to the service, recommendations, or good practices. Sainz highlights:

More than half of pieces are among the most seen contents of the day, therefore, they are reporting audience, although that is not its purpose but instead the dissemination, because some of rumours could even put the health of people at stake.

In this sense, from Euskal Irrati Telebista they expect the continuity of the service beyond the healthcare crisis, because now there is a basis and some contacts that allow to keep it, therefore assuming an essential function in the digital communicational context.

The fact-checked contents are presented in a bilingual format in the website of the EiTB group, despite not receiving any hoax in Euskera whatsoever. These texts are structured with a newsworthy headline and a body text, where all aspects that have been fact-checked have been detailed. The contrasted information also shows the word "FAKE" in red coloured, large size font (Image 2). Coronabulos also uses the Facebook (EiTB Albisteak-Noticias EiTB, 15,176 followers) and Twitter (@eitbNoticias, 142.129 followers and @eitbAlbisteak, 17,911 followers) profiles to post denials. Sainz states:

Furthermore, in Facebook we have 110 local communities of towns and populations of the Basque and Navarre autonomous communities and whenever there is something of specific interest in a region, it is posted on these channels.

The service also contributes to manage uncontrolled claims for help, which can collapse telephone landlines of healthcare professionals or generate and extra workload for them. Sainz points out:

This is what happened, for instance, with the requests of Basque hospitals to get diving masks on 28 March or the donation of plasma from healed patients on 10 April. 


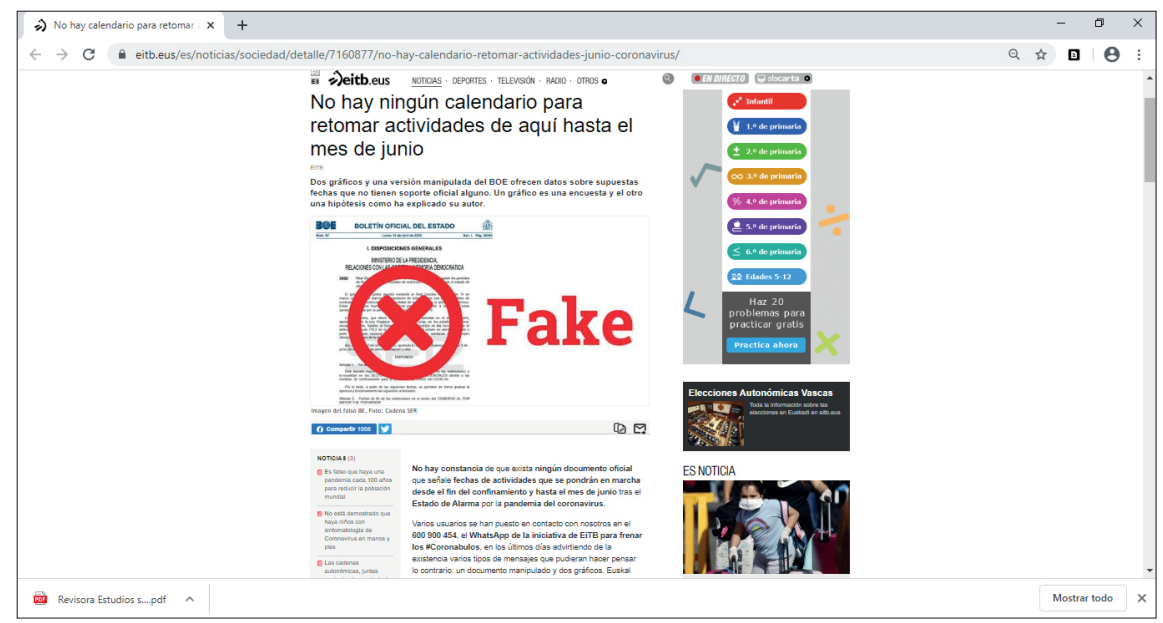

Source: <https://www.eitb.eus/>.

\section{COMPARISON OF RESULTS}

The fact-checking teams object of study emerge from digitalisation and innovation departments, like services linked to the web, because it is the environment in which the viralisation of fake news is produced (Table 2). The purpose of both teams is the same: to combat disinformation and to fact-check pernicious contents that circulate through the different platforms during the coronavirus crisis, in order to provide citizens a public service of quality, rigorous and ethical. In addition, these are projects that keep collaboration networks with different entities, displaying their will and ability to become scalable (Carvajal-Prieto, 2015).

The two departments analysed coincide in the fact that the starting up of these initiatives requires multidisciplinary, flexible teams and with specific technological competencies. In the case of Verifica RTVE, they have documentalists, digital journalists and fact-checking experts, while in Coronabulos there are journalists and web analysts. Therefore, the profile of the journalist is redefined, as a flexible figure and with the ability to ally with quite different profiles for the development of his profession.

On the contrary, the initiatives analysed differ in the method used for fact-checking. Verifica RTVE uses a detailed process that monitors social networks. The screening is done using technological tools and the selection and fact-checking is made by the human staff. On the other hand, EiTB does not have a specific workflow, turning to primary and official sources instead, as well as scientific experts, to perform the fact-checking process. There are also differences in the number of fact-checked texts. Verifica RTVE sums a total of 152 pieces from 17 March until 17 April, while Coronabulos accumulates 56, out of which $32.14 \%$ corresponds to hoaxes that refer to the Basque Country. 
Nevertheless, both services fact-check the same sort of contents: questions related to healthcare and pseudo-scientific information or "miracle products" (21.71\% in RTVE and $46.24 \%$ in EiTB). Likewise, the official communications issued by specific entities or information related to legal aspects in the state of alarm (13.46\% in RTVE and 19.6\% in EiTB). The fact-checking that refer to political figures are a minority (8.3\% in RTVE and 3.57\% in EiTB). These are object of attention of fact-checking companies such as Newtral or Maldita.es. Another front is the alert about possible technology related frauds, sometimes innocuous for the recipient (the hoax about "trap calls", in which the charge for calling back to a specific number is 1,500 Euros) and in other cases linked to what is known as phishing, an identity fraud felony to obtain personal data or users passwords by means of supposed promotion advertisements. These cases represent $11.18 \%$ of the denied hoaxes in RTVE and $3.57 \%$ in EiTB.

In general, these contents circulate through social networks and instant messaging platforms like WhatsApp, although sometimes it is decontextualized material. Verifica RTVE denied crowds in Atocha based on a picture taken by an individual that dated back to 2019 where there were agglomerations in the public transport. Information from La Razón that date back to October 2019 was also fact-checked, it was about cuts in the number of Italian deputies and senators that was presented as a recent decision to serve as an example for Spain.

Likewise, there are similarities in the way of publishing and spreading denials. In both cases, they are published in the respective corporate websites with a similar structure to that of the journalistic news: a headline and a body text where the hoax origin is explained, along with the fact-checking steps conducted, a final resolution and, sometimes, a recommendation. Likewise, both initiatives publish the fact-checks on their social networks profiles.

Table 2. Sample characteristics

\begin{tabular}{l|l|l} 
Name of the company & Verifica RTVE & \multicolumn{1}{l}{ Coronabulos } \\
\hline Objective & $\begin{array}{l}\text { Fact-check hoaxes related to COVID-19 that get viral during lockdown, in order to } \\
\text { offer citizens a public service of quality, rigorous and ethical }\end{array}$ \\
\hline Staff & $\begin{array}{l}\text { Profile Hybridization } \\
8 \text { individuals }\end{array}$ & $\begin{array}{l}\text { Profile Hybridization } \\
\text { 3 individuals }\end{array}$ \\
\hline Collaborations & European Broadcasting Union & $\begin{array}{l}\text { Maldito Bulo, "La Mecánica del } \\
\text { Caracol" and VOST Euskadi }\end{array}$ \\
\hline Fact-checking method & $\begin{array}{l}\text { Social networks, technological tools, } \\
\text { and staff }\end{array}$ & $\begin{array}{l}\text { Primary and official sources and } \\
\text { scientific experts }\end{array}$ \\
\hline Main themes & $\begin{array}{l}\text { Healthcare, pseudo-scientific information or "miracle products" and official or } \\
\text { legal fake statements causing alarm }\end{array}$ & 56 \\
\hline Pieces published & \begin{tabular}{l} 
Web, social networks, television, radio \\
\hline Dissemination routes
\end{tabular} & Web, social networks \\
\hline
\end{tabular}


The audience data seem to endorse users' response. In the case of RTVE and according to the source of analysis Adobe Analytics, the news of Verifica RTVE reached 385,633 unique users in April, with almost half million visits. On the other hand, EiTB uses Google Analytics and according to this meter the news website of the group, both in the Euskera and Spanish version, obtained 4,640,968 unique users between 17 March and 17 April, where more than 600,000 were reported by pieces published in the "Coronabulos" section. Furthermore, out of the 25 most seen pieces in this period, five correspond to contents elaborated by the fact-checking service.

\section{DISCUSSION AND CONCLUSIONS}

The research conducted considers that the goal initially established was achieved. The objective of analysing the structure, work methodology and publication of denials made by the specific fact-checking sections created in Spanish public audiovisual media to combat fake news about coronavirus.

The initiatives studied have emerged to fact-check the hoaxes related to the healthcare crisis, thus evidencing the will of consolidating this public service activity, that prioritises the civic agenda and the surveillance of public power when the boom of fake news and post-truth jeopardises the quality standards and the credibility of media and journalists (Lewandowsky, Ecker, and Cook, 2017). Moreover, it is a new step in the promotion of the participation of publics, which queries, opinions and concerns are addressed to elaborate contents. The interactive nature of Internet, still with its risks in terms of disinformation increase, must be considered an incentive to stimulate fact-checking and, along with it, to increase reliability and dialogue between citizens and the public service media (Brevini, 2013).

The public media should become references in the face of hoaxes and fake news as the COVID-19 situation intensifies worldwide. According to the European Broadcasting Union (EBU, 25 March 2020), the European public has increasingly resorted to public service media to obtain pandemic related news, thus increasing the daily visualisation of news from public media, 14\% in average. One of the objectives established by the EBU members is to quickly respond to the situation by extending the programme offer and trying to answer all the doubts of the audience, therefore ending the "infodemics" of misleading information and fake news.

Although in Spain there are some companies that perform these fact-checking tasks with accredited experience, public media can add a hallmark of neutrality to fact-checking, which would reinforce their credibility, because some researchers like Pere Masip (Del Castillo, 2020) warn about the perception there is about ideological positions of some fact-checkers. On the other hand, in the case of proximity public television networks, their main potential lies in complementing the work conducted in the country in terms of their closer communities, and even more in regions where there are two co-official languages, like the Basque Country. The work of EiTB is headed this direction. 
María José Ufarte-Ruiz (mariajose.ufarte@ uclm.es) is a professor assistant doctor at the Faculty of Communication of the University of Castilla-La Mancha, where she teaches in the writing area. She has been a visiting professor at the University La Frontera (Chile) and at the University of Rome La Sapienza (Italy), has participated in various $\mathrm{R} \& \mathrm{D} \& \mathrm{i}$ projects and has academic research and teaching stays, both na-

Belén Galletero-Campos (belen.galletero@ uclm.es) is a professor assistant doctor at Faculty of Communication of the University of Castilla-La Mancha. She is part of the research team of two national $\mathrm{R}+\mathrm{D}$ projects and she has leaded research projects for entities such as the Women's Institute of Castilla-La Mancha and the NGO Plan Internacional. She has conducted research stays at Centro de Estudos

Ana María López-Cepeda (ana.lopezcepeda@uclm.es). Graduate in Journalism from the University of Santiago de Compostela (USC), in Law from UNED and PhD in Communication and Journalism from the University of Santiago de Compostela (USC). She is currently professor of the Faculty of Communication of the University of Castilla-La Mancha (UCLM). She is specialised in public media services in Europe. She is principal investigator of tional and international. This training together with the diversity of subjects and areas of knowledge that he has taught in the different university cycles (Bachelor, Bachelor, Doctorate and Master) demonstrate his versatility. Within the journalistic writing studies, he has specialized in two lines of research: the influence of emerging technologies on journalistic genres and the new journalistic narratives.

de Comunicação e Sociedade of the University of Minho (PT) and has collaborated in the projetc Re/media.Lab -Laboratório e Incubadora de Media Regionais project (University of Beira Interior, PT). Her scientific papers address developments and quality in television and local media. She is a member of the Advisory Board of Radio-Television Castilla-La Mancha on behalf of the University of Castilla-La Mancha.

the Research Group in Sociology of Communication at the University of Castilla-La Mancha and principal investigator of the research project "Indicators of profitability in the media for regional development", funded by the Gobierno de Castilla-La Mancha. She working in a I+D project about New values, governance, financing and audiovisual services public for the Internet society led by the USC.

\section{References}

Abellán, L. (2020, 19 April). "La pandemia se convierte en 'infodemia'". El País. Available at: $<$ https://cutt.ly/qyqSsLi>. Accessed 1 May 2020.

Alandete, D. (2019). Fake News: La nueva arma de destrucción masiva. Barcelona: Deusto SA Ediciones.

Allcott, H. and Gentzkow, M. (2017). "Social Media and Fake News in the 2016
Election". Journal of Economic Perspectives, 31(2), pp. 211-236. DOI: <https://www.doi. org/10.1257/jep.31.2.211>.

Amazeen, M. A. (2015). "Revisiting the Epistemology of Fact-Checking". Critical Review, 27(1), pp. 1-22. DOI: <https://doi.org/1 $0.1080 / 08913811.2014 .993890>$. 
Amorós, M. (2018). Fake News. La verdad de las noticias falsas. Barcelona: Plataforma Editorial.

Arcila-Calderón, C.; Barbosa-Caro, E., and Cabezuelo-Lorenzo, F. (2016). “Técnicas 'big data': Análisis de textos a gran escala para la investigación científica y periodística". El Profesional de la Información, 25(4), pp. 623-631. DOI: <http://dx.doi.org/10.3145/epi.2016.jul.12>.

Ayuso, B. and Bauzá, B. (2018). "Almanacs, Spies and a Tracksuit: The Secret Universe of Fact-Checkers". Jot Down, no. 31 (April), pp. 4-13.

Balmas, M. (2012). "When Fake News Becomes Real. Combined Exposure to Multiple News Sources and Political Attitudes of Inefficacy, Alienation, and Cynicism". Communication Research, 41, pp. 430-454. DOI: <https:// doi.org/10.1177/0093650212453600>.

Bardin, L. (1977). Análise de conteúdo. Lisboa: Edições 70.

Barragán-Romero, A. I. and Bellido-Pérez, E. (2019). “'Fake News' durante la Primera Guerra Mundial: Estudio de su representatividad en las portadas de la prensa española (ABC Madrid)". Historia y Comunicación Social, 24 (2), pp. 433-447.

Blanco-Alfonso, I.; García-Galera, C., and Tejedor-Calvo, S. (2019). "El impacto de las 'fake news' en la investigación en Ciencias Sociales. Revisión bibliográfica sistematizada". Historia y Comunicación Social 24 (2), pp. 449-469.

Blanco-Herrero, D. and Arcila-Calderón, C. (2019). "Deontología y noticias falsas: estudio de las percepciones de periodistas españoles". El Profesional de la Información, 28 (33), pp. 1-13. DOI: <https://doi.org/10.3145/ epi.2019.may.08>.

Bloch, M. (1999). Historia e historiadores. Madrid: Akal.

Brevini, B. (2012). Public Service Broadcasting Online: A Comparative European Policy Study of PSB 2.0. London: Palgrave.

Burkhardt, J. M. (2017). "Chapter 1. History of Fake News". Library Technology Reports, 53(8), pp. 5-9.
Cambridge Dictionary. (2018). Significado de 'fake news'. Available at: <https://cutt.ly/ oyr4VzQ>. Accessed 19 April 2020.

Carvajal-Prieto, M. (2015). "Economía del periodismo: Modelos de negocio en la era de las plataformas". Available at: <http://cort.as/RYtL >. Accessed 15 March 2020.

Casero-Ripollés, A. and Cullell-March, C. (2013). "Periodismo emprendedor. Estrategias para incentivar el autoempleo periodístico como modelo de negocio". Estudios sobre el Mensaje Periodístico, 19, no. Special April, pp. 681-690. DOI: <https://doi.org/10.5209/rev_ ESMP.2013.v19.42151>.

Castillo, C. del (2020, 14 April). "Casi un $70 \%$ de los españoles ha recibido bulos sobre el coronavirus a través de Whatsapp, según un nuevo estudio". Eldiario.es. Available at: <https:// cutt.ly/xyr4vT6 >. Accessed 14 April 2020.

Catalina-García, B.; Sousa, J. P., and Cristina-Silva Sousa, L. C. (2019). “Consumo de noticias y percepción de 'fake news' entre estudiantes de Comunicación de Brasil, España y Portugal". Revista de Comunicación, vol. 18, no. 2, pp. 93-115 DOI: <https://doi.org/10.26441/ RC18.2-2019-A5>.

Champy, F. (2011). Nouvelle théorie sociologique des professions. Paris: Presses Universitaires de France.

Cherubini, F. and Graves, L. (2016). "The Rise of Fact-Checking Sites in Europe". Reuters Institute for the Study of Journalism, University of Oxford. Available at: <https://cutt.ly/ hyLG09s>. Accessed 18 November 2019.

Codeluppi, V. (2018). Il tramonto della realtà. Come i media trasformano le nostre vite. Milano: Carocci.

Codina, L. (2017). Revisiones sistematizadas y cómo llevarlas a cabo con garantías: Systematic reviews y SALSA Framework. Available at: <https://cutt.ly/7wXGp1b>. Accessed 18 November 2019.

Colpisa (2020, 7 April). "Las cadenas autonómicas, juntas contra los 'coronabulos'. Laverdad.es. Available at: <https://cutt.ly/ Pyr4kFG>. Accessed 7 April 2020. 
Comisión Europea (2020, 14 April). "Respuesta al coronavirus". Available at: <https://cutt.ly/yyq3ZMW>. Accessed 14 April 2020.

Delgado López-Cozar, E. and MartínMartín, A. (2020). "La viralidad de la ciencia defectuosa: El contagioso impacto mediático de un peprint en bioRxiv sobre el coronavirus y sus efectos en la comunicación científica". DOI: <https://doi.org/10.13140/ RG.2.2.12666.44485>.

Derakhshan, H. and Wardle, C. (2017). "Information Disorder: Definitions". In: AA VV. Understanding and Addressing the Disinformation Ecosystem, pp. 5-12. Pennsylvania: Annenberg School for Communication.

EBU (2020a, 31 March). "The Coronavirus and Public Service Media: Why Digital Transformation Matters Now More Tan Ever". Available at: <https://cutt.ly/8yr4WJl>. Accessed 31 March 2020.

-. (2020b, 3 April). "Coronavirus Crisis - EBU Calls on Governments to Uphold Independence of Public Service Media". Available at: <https://cutt.ly/Dyr4Y2M>. Accessed 3 April 2020.

-. (2020c, 25 March). "Public Service Media Are Trusted Source of Information on COVED-19 Crisis". Available at: <https://cutt. ly/myr4PdV>. Accessed 25 March 2020.

Fisher, C. (2018). "What Is Meant by 'Trust' in News Media?" In: Otto, K. and Köhler, A. (eds.). Trust in Media and Journalism, pp. 19-38. Berlin: Springer.

Gaitán-Moya, J. A. and Piñuel-Raigada, J. L. (1998). Técnicas de investigación en comunicación social: Elaboración y registro de datos. Madrid: Síntesis.

García-Avilés, J. A. and Carvajal, M. (2008). "Integrated and Cross Media Newsroom Convergence: Two Models of Multimedia News Production: The Cases of Novotécnica and La Verdad Multimedia in Spain". Convergence, 14(2), pp. 223-241.

Gómez-Diago, G. (2010). “Triangulación metodológica: Paradigma para investigar des- de la ciencia de la comunicación". Razón y Palabra, 72.

Graves, L. (2016). "Anatomy of a Fact Check: Objective Practice and the Contested Epistemology of Fact Checking". Communication, Culture \& Critique, 10(3), pp. 518 537. DOI: <https://www.doi.org/10.1111/ cccr.12163>.

Greenberg, D. (2017). “Deciding What's True: The Rise of Political Fact-Checking in American Journalism". Journal of Communication, vol. 67. DOI: <https://doi.org/10.1111/ jcom.12329>.

Gueham, F. (2017). Le fact-checking: une réponse à la crise de l'information et de la démocratie. Paris: Fondation pour l'Innovation Politique.

Haigh, M.; Haigh, T., and Kozak, N.-I. (2017). "Stopping Fake News. The Work Practices of Peer-to-Peer Counter Propaganda". Journalism Studies, 25 April, pp. 1-26. DOI: <https://doi.org/10.1080/1461670X.2017. 1316681>.

Herring, S. (2010). "Web Content Analysis: Expanding the Paradigm". In: Hunsinger, J.; Klastrup, L., and Allen, M. M. (eds.). International Handbook of Internet Research. New York: Springer Verlag, pp. 233-249.

Jang, S. M. and Kim, J. K. (2018). “Third Person Effects of Fake News: Fake News Regulation and Media Literacy Interventions". Computers in Human Behavior, 80, pp. 295-302.

Jankowski, N.W. (2018). "Researching Fake News: A Selective Examination of Empirical Studies". Journal of the European Institute for Communication and Culture, 25, pp. 248-255. DOI: <https://doi.org/10.1080/13183222.201 8.1418964>.

Khaldarova, I. and Pantti, M. (2016). "Fake News. The Narrative Battle over the Ukrainian Conflict". Journalism Practice, 12 April, 10, pp. 891-901. DOI: <https://doi.org/10.1080/1751 2786.2016.1163237>.

Krippendorf, K. (2004). Content Analysis: An Introduction to Its Methodology. 2nd ed. Thousand Oaks, CA: Sage. 
Lewandowsky, S.; Ecker, U. K., and Cook, J. (2017). Beyond Disinformation: Understanding and Coping with the "Post-Truth" Era. Journal of Applied Research in Memory and Cognition. Available at: <http://cort.as/RaYR>.

López-Cepeda A. M.; Ufarte-Ruiz, M. J., and Murcia-Verdú, F. J. (2019). “Audiovisual Media for Public Service and Disinformation. Top Policies and Strategies Against Fake News". In: Hidalgo-Marí; Segarra-Saavedra; Álvarez-Nobell; Trenta (coords.). Las nuevas narrativas en el entorno social. Tenerife: Cuadernos Artesanos de Comunicación.

López-García, X; Toural-Bran, C., and Rodríguez-Vázquez, A. I. (2016). "Software, estadística y gestión de bases de datos en el perfil del periodista de datos". El Profesional de la Información, 25(2), pp. 286-294. DOI: <http://dx.doi.org/10.3145/epi.2016.mar. $16>$.

López-Vidales, N.; González-Aldea, P., and Medina de la Viña, E. (2011). “Jóvenes y televisión en 2010: Un cambio de hábitos". Zer, Revista de Estudios de Comunicación, 16(30), pp. 97-113.

Lowrey, W. (2017). "The Emergence and Development of News Fact-checking Sites". Journalism Studies, 18(3), pp. 376-394. DOI: <https://www.doi.org/10.1080/146167 0X.2015.1052537>.

Macías-Varela, B. (2017). La comunicación para el cambio social desde una perspectiva de género en Andalucía. Doctoral thesis. University of Cadiz.

Magallón-Rosa, R. (2019). Unfaking News: Cómo combatir la desinformación. Madrid: Ediciones Pirámide.

Mantzarlis, A. (2018). "Fact-Checking 101". In: Ireton, Ch. and Posetti, J. Journalism Fake News \& Disinformation: Handbook for Journalism Education and Training. France: Unesco, pp. 85-100.

McChesney, R. (2014). Blowing the Roof off the Twenty-First Century. New York: Monthly Review Press.
Mihailidis, P. and Viotty, S. (2017). "Spreadable Spectacle in Digital Culture: Civic Expression, Fake News, and the Role of Media Literacies in 'Post-Fact' Society". American Behavioral Scientist, 61(4), pp. 441-454. DOI: <https://doi. org/10.1177/0002764217701217>.

Nyhan, B. and Reifler, J. (2014). "The Effect of Fact-Checking on Elites: A Field Experiment on Us State Leigslators". American Journal of Political Science 56 (3), pp. 628-640. DOI: <https://doi.org/10.1111/ajps.12162>.

Paniagua-Rojano, F. J.; Gómez-Aguilar, M. and González-Cortés, M. E. (2014). "Incentivar el emprendimiento periodístico desde la Universidad". Revista Latina de Comunicación Social, 69, pp. 548-570. DOI: <https://doi.org/ 10.4185/RLCS-2014-1024>.

Pavlik, J. V. (2013). "Innovation and the Future of Journalism”. Digital Journalism, 1(2), pp. 181-193. DOI: <https://doi.org/10.1080/2 1670811.2012.756666>.

Pérez-Dasilva, J. Á.; Meso-Ayerdi, K., and Mendiguren-Galdospín, T. (2020). “'Fake news' y coronavirus: Detección de los principales actores y tendencias a través del análisis de las conversaciones en Twitter". El Profesional de la Información, vol. 29, no. 3, e290308. DOI: <https://doi.org/10.3145/epi.2020.may. $08>$.

Petroni, S.; Massa, A., and Anzera, G. (2017). Lo specchio di Aletheia: Fake news e politica internazionale. Vol. 1. Edizioni Nuova Cultura.

Rapp, D. N. and Salovich, N. A. (2018). “Can't We Just Disregard Fake News? The Consequences of Exposure to Inaccurate Information". Policy Insights from the Behavioral and Brain Sciences, 5(2), pp. 232-239 DOI: <https:// doi.org/10.1177/2372732218785193>.

Renó, L. and Flores, J. (2014). "Periodismo de datos en el mundo transmedia". In: Campalanis, C.; Renó, D., and Gosciola, V.: Narrativas transmedia: Entre teorías y prácticas. Barcelona: Oberta Press.

Rivas de Roca, R.; García-Gordillo, M., and Caro-González, F. J. (2020). “La construcción 
del periodismo 'localizado' en medios digitales europeos. Estudio de casos". Revista Latina de Comunicación Social, 75, pp. 1-26. DOI: <https:// www.doi.org/10.4185/RLCS-2020-1414>.

Salas-Abad, C. (2019). "La primera 'fake news' de la historia". Historia y Comunicación Social, 24 (2), pp. 411-431.

Schudson, M. and Zelizer, B. (2017). "Fake News in Context". In: AA VV. Understanding and Addressing the Disinformation Ecosystem, pp. 1-4. Pennsylvania: Annenberg School for Communication.

Soler-Pujals, P. and Enríquez-Jiménez, A. M. (2012). "Reflexión sobre el rigor científico en la investigación cualitativa". Estudios sobre el Mensaje Periodístico, 18, pp. 879-888. DOI: $<$ https://doi.org/10.5209/rev_ESMP.2012. v18.40966>.

Spivak, C. (2011). "The Fact-Checking Explosion". American Journalism Review 32 (4), pp. 38-43.

Stencel, M. (2016). Global Fact-Checking up 50\% in Past Year. Duke Reporters's Lab. Available at: <http://cort.as/-RRUO >. Accessed 1 May 2020.

Tandoc, E. C.; Lim, Z. W., and Ling, R. (2018). "Defining 'Fake News': A Typology of Scholarly Definitions". Digital Journalism, 6(2), pp. 137-153 DOI: <https://doi.org/10.1080/21 670811.2017.1360143>.

Toledano, S. and Ardèvol-Abreu, A. (2013). "Los medios ante las catástrofes y crisis humanitarias: Propuestas para una función social del periodismo". Comunicación y Sociedad, 26 (3), pp. 190-213.

Ufarte-Ruiz, M. J.; Anzera, G., and Murcia-Verdú, F. J. (2020). "Independent
Fact-Checking Platforms in Spain and Italy. Characteristics, Organization and Method". Revista Mediterránea de Comunicación, 11(2), DOI: <https://www.doi.org/10.14198/MEDCOM2020.11.2.3>.

Ufarte-Ruiz, M. J. and Manfredi-Sánchez, J. L. (2019). "Map of Data Verification Projects in Spain: Professional Profile, Skills and Organization". Nuevos perfiles profesionales para el mercado periodístico. Salamanca: Comunicación Social, pp. 85-104.

Ufarte-Ruiz, M. J.; Peralta-García, L., and Murcia-Verdú, F. J. (2018). "Fact Checking: A New Challenge for Journalism". El Profesional de la Información, vol. 27, no. 4, pp. 733741. DOI: <https://doi.org/10.3145/epi.2018 jul.02>.

Uscinski, J. E. and Butler, R. W. (2013). "The Epistemology of Fact Checking". Critical Review. A Journal of Politics and Society, 25, pp. 162-180. DOI: <https://doi.org/10.1080/0891 3811.2013.843872>.

Vizoso, Á. and Vázquez-Herrero, J. (2019) "Fact-Checking Platforms in Spanish. Characteristics, Organization and Method". Comunicación y Sociedad, 32(1), pp. 127-144.

Vosoughi, S.; Roy, D., and Aral, S. (2018) "The Spread of True and False News Online". Science, 359(6380), pp. 1146-1151.

Warldle, C. and Derakhshan, H. (2017). Information Disorder. Toward an Interdisciplinary Fra-Mework for Research and Policymaking. Estrasburgo: Council of Europe report DGI

Zaryan, S. (2017). Truth and Trust: How Audiences Are Making Sense of Fake News. Lund: Lund University. 
